\title{
The Effect of Etanercept Therapy on Adrenal Steroid Metabolism in Juvenile Idiopathic Arthritis: A Steroid Metabolomics Approach
}

Yonatan Butbul Aviel ( $\nabla$ yonatanbutbul@gmail.com )

Rambam Health Care Campus

\author{
Ariel Keinan \\ Rambam Health Care Campus \\ Michaela Hartmann \\ University of Giessen \\ Stefan Wudy \\ University of Giessen \\ Dov Tiosano \\ Rambam Health Care Campus
}

\section{Research Article}

Keywords: Juvenile Idiopathic Arthritis, Steroid, Metabolomics, GC-MS, anti-TNFa

Posted Date: December 8th, 2021

DOI: https://doi.org/10.21203/rs.3.rs-1092539/v1

License: (c) (i) This work is licensed under a Creative Commons Attribution 4.0 International License. Read Full License 


\section{Abstract \\ Objective}

To evaluate the impact of anti-tumor necrosis factor-alpha (TNFa: etanercept [Enbrel $\circledast$ ]) on adrenal activity in the acute phase of juvenile idiopathic arthritis (JIA) during which there is a decrease in adrenal androgen and cortisol levels.

\section{Method}

Eleven JIA patients aged $12 \pm 6.2$ years with a disease duration of $6.3 \pm 5.2$ years were enrolled. They were treated once weekly with etanercept $(0.8 \mathrm{mg} / \mathrm{kg})$ for $3 \pm 2.8$ years. Urine samples for gas chromatography-mass spectrometry steroid hormone analysis were collected before, and 1 and 3 days after etanercept injection and compared to age- and sexmatched healthy control.

\section{Results}

The levels of 23 of the 35 metabolites were low before etanercept treatment. Those 23 metabolites included $2 \mathrm{C}_{19}$ steroids (androgens), $3 \mathrm{C}_{21}$ steroid hormone intermediates, 14 cortisol metabolites, 2 corticosterone metabolites and 2 $\mathrm{C}_{18}$ steroids (estrogens). One day post-treatment, only 5 of the 23 metabolite levels remained low. They included $2 \mathrm{C} 19$ metabolites, 221 steroid metabolites and 1 cortisol metabolite b-c. Three days post-treatment, the only metabolite levels that continued to be low were 1 C19 metabolite, 2 C21 steroid hormone intermediates and 1 cortisol metabolite (a-Cl), while the remaining 18 metabolites had already normalized after 1 day. DHEAS and $17 \mathrm{OH}$ pregnenolone metabolite levels were the last ones to recover. Urinary metabolite ratios reflecting CYP21 and 11 $\beta$-HSD2 enzymatic activities were lower in JIA patients than in controls.

\section{Conclusion}

Almost all of the pre-etanercept treatment cortisol urinary metabolite levels were significantly lower than normal, and almost all rose to normal values by 1 day post-treatment. Blocking TNFa restores adrenal function in JIA.

\section{Key Messages}

\section{What is already known about this subject?}

- Serum cortisol concentrations are disproportionally low relative to the level of inflammation in rheumatoid arteritis (RA) and other inflammatory diseases.

- Tumor necrosis factor-alpha (TNFa) is elevated in the serum and the synovial fluid in children with juvenile idiopathic arthritis (JIA).

- Anti-TNFa treatment has an effect on the hypothalamic-pituitary-adrenal axis and improves adrenal hormone secretion in adults with RA. Comparable findings were never confirmed in pediatric JIA patients.

\section{What does this study add?}

- Anti-TNFa treatment has a rapid effect on urine adrenal metabolites in children with JIA. 
- The therapeutic effect of anti-TNF treatment in JIA may be related to its effect on the restoration of adrenal function and cortisol levels.

\section{How might this impact on clinical practice or future developments?}

- The current study introduces the concept that the urinary steroid metabolome is suitable for assessing and monitoring the disease activity in JIA as well as for predicting disease flare.

\section{Introduction}

Juvenile idiopathic arthritis (JIA) is the most common rheumatic disease in children and a major cause of functional disability. The chronic inflammatory synovitis and systemic features of JIA are mediated by the cytokine products of an activated immune system. Among the many cytokines that are involved in the acute phase, the levels of interleukin- 6 (IL-6), IL-8 and tumor necrosis factor alpha (TNFa) are the most predominantly elevated. TNFa is one of the proinflammatory cytokines that has a complex role in the pathogenesis of rheumatoid arthritis (RA). [1][2]. It is also elevated in the serum and in the synovial fluid in children with juvenile rheumatoid arthritis (JRA) [3].

Cortisol is a major anti-inflammatory substance whose low levels during the evening and night are linked to an increase in proinflammatory cytokines, such as TNFa and IL-6, during the early morning. That rise in cortisol levels in the early morning is related to the inhibition of inflammation by cytokines during the day [4] This cortisol circadian rhythm is clinically linked to pain and stiffness, which are prominent during the early morning in RA. Several studies have observed that serum cortisol concentrations in RA and other inflammatory diseases are disproportionally low relative to the level of inflammation [5]. The hypocortisolemia in JIA may result either from primary or secondary hypoadrenalism. The endocrine profile in some untreated RA patients revealed elevated adrenocorticotropic hormone (ACTH) levels without hypercortisolemia, a combination that reflects resistance to ACTH or the presence of primary hypoadrenalism [6][7]. These observations correspond with a seminal study which showed that TNFa is a potent inhibitor of adrenocorticotropin-induced cortisol production and steroidogenic P450 enzyme gene expression in cultured human fetal adrenal cells.[8] Other studies in patients with active JIA showed low levels of ACTH, serum cortisol and urinary free cortisol, a combination that reflects a disturbance in the hypothalamic pituitary adrenocortical axis (HPA).

Etanercept $\left(\right.$ Enbrel ${ }^{\circledR}$, Immunex, Seattle), a genetically engineered fusion protein consisting of 2 identical chains of the recombinant extracellular human TNF-receptor p75 monomer fused with the Fc domain of human immunoglobulin1, effectively binds TNFa and lymphotoxin-a and inhibits their activity. Treatment with etanercept reportedly leads to significant improvement in patients with active polyarticular JRA [8].

The aim of this study was to evaluate the role of etanercept on adrenal steroid hormone metabolism by assessing the urinary steroid metabolome in JIA.

\section{Methods}

\section{Patients}

The study group was composed of all consecutive patients who were treated with once weekly etanercept injections and followed in the Pediatric Rheumatology Service in Rambam Hospital (Haifa, Israel), all methods were performed in accordance with the relevant guidelines and regulations. An age- and sex-matched healthy control was matched to each patient. The diagnosis of JIA was made according to the JIA criteria of the International League of Associations for Rheumatology classification [9]. Disease severity was evaluated by measuring the number of active joints and C- 
reactive protein (CRP) levels. Patients who were treated with corticosteroids by oral or intra-articular injection during the preceding 3 months were excluded.

\section{Methods}

Urinary samples were obtained from all patients. The first sample was collected on the day before Enbrel injection. The second and the third samples were collected one day and three days after the injection. One urine sample was obtained from healthy controls. All urine samples were spot urines from first morning voiding.

Urinary steroid metabolites were analyzed by using quantitative data that were generated by gas chromatography-mass spectrometry (GC-MS) analysis as described previously[10]. In brief, free and conjugated urinary steroids were extracted by solid phase extraction, and conjugates were enzymatically hydrolyzed. After recovery of hydrolyzed steroids by solid phase extraction, known amounts of internal standards (5a-androstane-3a, 17a-diol, stigmasterol) were added to each extract before formation of methyloxime-trimethylsilyl ethers. GC was performed using an Optima-1 fused silica column housed in an Agilent Technologies 6890 series GC that was directly interfaced to an Agilent Technologies 5975 mass selective detector. Injections were made into an $80^{\circ} \mathrm{C}$ ( $2 \mathrm{~min}$ ) oven, in which the temperature was increased by $20^{\circ} \mathrm{C} / \mathrm{min}$ to $190^{\circ} \mathrm{C}(1 \mathrm{~min})$. To separate steroids the temperature was subsequently increased by $2.5^{\circ} \mathrm{C} / \mathrm{min}$ to $272^{\circ} \mathrm{C}$. For each analyte the monitoring of two typical fragment ions (target ion and qualifier ion) ensured specificity. Quantitation took place in the linear range of the calibration plots of our analytes. Values of 35 metabolites identified by GC-MS were compared between JIA patients and healthy controls. This generated a metabolic profile of JIA patients before and after Enbrel treatment compared to healthy controls.

\section{Statistical analysis}

The results are expressed as mean \pm standard deviation for data showing normal distribution, and as median for data showing abnormal distribution. The paired T-test and the paired Wilcoxon test were applied to compare the data showing and not showing normal distribution of the repeated specimens, respectively, with that of the controls. Fisher's exact test was used to compare the number of metabolites whose values were significantly different from the control values, after which Bonferroni correction for multiple comparisons was applied. Significance was determined at $p$ values $<0.05$.

\section{Results}

Eleven JIA patients were enrolled into the study. There were 8 females and 3 males with an age range from 3 to 21 years. Five patients had polyarthritis, 3 had oligoarthritis, 2 had psoriatic arthritis, and 1 had systemic arthritis. The disease duration ranged from 2 to 18 years. The duration of etanercept treatment ranged from 6 months to 10 years. Two patients were also treated with methotrexate during the study (patients 1 and 2, table 1).

Thirty-five urinary metabolites that provide an integrated picture of human steroid hormone metabolism were analyzed before and after etanercept treatment (Fig -1). The levels of 23 of those 35 metabolites were significantly lower than normal before treatment. The 23 metabolites included 4 of the $11 \mathrm{C}_{19}$ steroids (androgens), $5 / 8 \mathrm{C}_{21}$ steroid hormone intermediates, $10 / 10$ cortisol metabolites, $2 / 3$ corticosterone metabolites and $2 / 3 \mathrm{C}_{18}$ steroids (Table 2). One day after etanercept treatment, only five out of the 23 metabolites remained significantly lower than normal in the JIA patients. Those five metabolites were $2 \mathrm{C}_{19}$ metabolites, androsterone (An) and 5a-androstane-3a, 11 $\beta$-diol-17-one (110H-An) and 221 steroids [pregnanediol (P5D preg) and 11-0-Pt (5b-Pregnane-3a, 17a, 20a-triol-11-on] (Table 2). Three days after etanercept treatment, only five metabolites were significantly low: $2 \mathrm{C}_{19}$ steroid metabolites An and $110 \mathrm{H}-\mathrm{An}, 2$ $\mathrm{C}_{21}$ intermediates Pt and P5D and 1 cortisol metabolite (a-Cl). 
None of the metabolites at any time during the collection was significantly higher in the JIA patients than in the control group. The metabolite ratios that reflect enzyme activities before etanercept treatment and 3 days following it are presented in Table 3. The ratio (THE+THF+aTHF)/PT that reflects the activity of CYP21 reached a p value of 0.06 , and the ratio of $((a-C)+(b-C)) /((a-C l)+(b-C l))$ that reflects the activity of the renal 11 $\beta-H S D 2$ reached a $p$ value of 0.07 .

\section{Discussion}

JIA is the most common rheumatic disease in children, with an incidence of 1.6-23 cases/100,000 [11]. The chronic inflammatory synovitis and systemic features of JIA are mediated by cytokine products of an activated immune system, including the TNFa, IL-1 and IL-6 axis. Anti-TNF is an effective therapy for modifying the course of JIA, and one that is usually administered as a second-line agent in treating patients with JIA [8].

Bilginer et al showed that JIA patients with active disease have low early morning serum cortisol levels as well as low ACTH levels that correlate with high IL-6 levels as seen in active disease [12], representing a combination that can reflect hypophysitis or possible hypothalamic involvement. In line with that observation, the findings that urinary-free cortisol levels in active JIA patients are lower than those in healthy controls and that they rise during periods of remission in parallel to the serum cortisol levels suggest that the activity of the HPA axis is affected during the active phase of JIA [12][13]. During remission, JIA patients reportedly have normal cortisol levels in the presence of high ACTH levels, a finding that may suggest partial resistance to ACTH [14].

TNF has an important role in the pathogenesis of JIA. Patients with JIA have high levels of TNFa in inflamed joints, and anti-TNF is a very potent therapy in JIA as it is in RA. Atzeni et al showed that anti-TNF therapy in adult RA patients normalized the HPA axis by increasing the ACTH and cortisol levels and by decreasing the ratio of ACTH to cortisol [15]. Those findings suggest that anti-TNF treatment has an effect on the HPA axis and that it improves adrenal hormone secretion, but comparable findings have never been reported in pediatric JIA patients [15][15][14][13][13][15].

The aim of the current study was to evaluate the role of anti-TNF therapy on the pediatric adrenal steroid hormone metabolism as reflected by urinary steroid metabolites determined by GC-MS. We found that 23 urine metabolite levels were significantly lower in JIA patients before they underwent etanercept treatment: 18 of them normalized 1 day posttreatment and only 5 remained lower than normal after 3 days. Interestingly, the levels of the $5 \mathrm{An}$ and $110 \mathrm{H} A n \mathrm{C}_{19}$ metabolites, Pt and P5D (that are $\mathrm{C}_{21}$ metabolites) and a-Cl (that is a cortisol metabolite) remained lower than normal 3 days after the treatment.

Jäättelä et al seminal study (8) showed that TNFa inhibits the expression of mRNAs of adrenal cytochrome P450 oxidases, P450scc (cholesterol side-chain cleavage enzyme/20.22-desmolase), P450c11 (11 beta-hydroxylase/18hydroxylase/18-methyl oxidase), P450c17 (17 alpha-hydroxylase/17, 20-lyase) and P450c21 (21-hydroxylase) in human fetal adrenals. The decrease in gene expression was accompanied by a decrease in cortisol but not in either dehydroepiandrosterone sulphate (DHEAS) or in androstenedione. All of the effects of TNFa were neutralized by the addition of monoclonal anti-TNFa antibody. These results demonstrated that TNFa suppresses the synthesis of cortisol and shifts the steroid secretory pattern towards androgen production, at least partially, by suppressing the accumulation of mRNAs for adrenal cytochrome P450 oxidases.

The estradiol metabolite levels were low in the 8 females before the administration of etanercept treatment. Given that testosterone is aromatized to estrogen by Cyp19, those low levels can be related to low testosterone levels produced by the effect of TNFa on P450c17 (17 alpha-hydroxylase/17, 20-lyase), and to the fact that TNF inhibits the conversion of DHEAS to DHEA in RA synovial cells [16]. 
The finding that four urine metabolites (An, Pt, P5D and a-Cl) remained significantly low 3 days after etanercept treatment may indicate that the enzymes that are involved in their metabolism are more affected by TNFa than the other enzymes. Urine metabolite ratios reflect enzymatic activities. There was no significant difference in most of those ratios between the control group and the patient group before and after etanercept treatment, whereas the ratios that

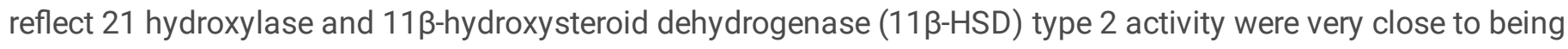
significantly different between the groups. That finding indicates that these 2 enzymes were more affected by Etanercept in the patient group. Notably, these 2 enzymes are involved in cortisol production and cortisol conversion to cortisone. Active cortisol is converted to inactive cortisone mainly by the kidney via $11 \beta$-hydroxysteroid dehydrogenase (11 $\beta$-HSD) type 2 in order to protect the nonspecific mineralocorticoid receptor from activation by cortisol. The liver is the major organ for converting inactive cortisone to active cortisol, and it does so via 11 $\beta$-HSD1. The expression of $11 \beta-$ HSD1 is enhanced by TNF and proinflammatory cytokines. The cytokine-induced increased expression of 11 $\beta$-HSD1 is mainly involved at the intracellular compartment, however, it can induce a change in the HPA axis [17].

Although most of the patients in the current study were either free of active disease or had mild disease activity, their urine cortisol metabolites were nevertheless low compared to the normal controls. One of the challenges in treating JIA patients is to decide when to stop treatment, such as anti-TNF, and to try to predict who will need to resume therapy. Toward this end, the interrupted HPA axis in JIA patients with active as well as subclinical disease may be able to identify the patients for whom it is safe to stop therapy, given that the recovery of the HPA axis improves not only the inflamed joints but also other important health aspects, such as growth, bone health and general wellbeing.

Our study has a few limitations that bear mention. The main limitation is our small number of patients, and another is their range of ages and different stages of sexual development that may influence the HPA axis. We tried to overcome this latter limitation by matching them with a control group by age and Tanner stage development. Another drawback is that we do not have 24-hour urinary samples to precisely calculate the excretion rates of urinary steroid hormone metabolites and thereby assess hormonal production rates. Although our study population is limited, we were able to show that most of patients with JIA have an interrupted HPA axis and that anti-TNF therapy was able to correct it.

\section{Conclusions}

The findings of the current study demonstrated that anti-TNFa treatment has a rapid effect on urine adrenal metabolites in children with JIA. The therapeutic effect of anti-TNF treatment in JIA may be related to its effect on the restoration of adrenal function and cortisol levels. We propose that the urinary steroid metabolome is suitable for assessing and monitoring the disease activity in JIA as well as for predicting disease flare. A larger study is warranted to confirm our findings and to evaluate whether the urinary steroid metabolome can be used as a predictor to assess and monitor disease activity and serve as a predictor for disease flare.

- Subheading- Anti-TNFa treatment has a rapid effect on urine adrenal metabolites in children with JIA. The therapeutic effect of anti-TNF treatment in JIA may be related to its effect on the restoration of adrenal function and cortisol levels. steroid metabolome is suitable for assessing and monitoring the disease activity in JIA as well as for predicting disease flare.

\section{Abbreviations Of Steroids}




\begin{tabular}{|c|c|}
\hline An & 5a-Androstane-3a-ol-17-one (Androsterone) \\
\hline Et & $5 \beta$-Androstane-3a-ol-17-one (Etiocholanolone) \\
\hline DHEA & 5-Androstene-3ß-ol-17-one (Dehydroepiandrosterone) \\
\hline 16 a-OH-DHEA & 5-Androstene-3ß,16a-diol-17-one \\
\hline A5-3ß,17a a & 5-Androstene-3 $\beta, 17 a$-diol diol \\
\hline$A 5-3 \beta, 17 \beta$ & 5-Androstene-3 $\beta, 17 \beta$-diol (Androstenediol-17 $\beta$ ) \\
\hline A5T- $16 a$ & 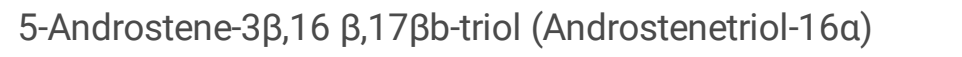 \\
\hline PD & $5 \beta$-Pregnane-3a,20a-diol (Pregnanediol) \\
\hline PT & $5 \beta$-Pregnane-3a,17a,20a-triol (Pregnanetriol) \\
\hline P5D & 5-Pregnene-3 $\beta, 20 a-d i o l$ (Pregnanediol) \\
\hline P5T-17a & 5-Pregnene-3 $\beta, 17 a, 20 a$-triol (Pregnenetriol-17a) \\
\hline Po-5 $5,3 a$ & 5ß-Pregnane-3a,17adiol-20-one (17a-OH-Pregnanolon) \\
\hline Po-5a,3a & 5a-Pregnane-3a,17a-diol-20-one \\
\hline $\mathrm{F}$ & 4-Pregnene-11ß,17a,21-triol-3,20-dion (Cortisol) \\
\hline THE & $5 \beta$-Pregnane-3a,17a,21-triol-11,20-dion (TH-Cortisone) \\
\hline THF & $5 \beta$-Pregnane-3a,11ß,17a,21-tetrol-20-one (TH-Cortisol) \\
\hline a-THF & 5a-Pregnane-3a,11ß,17a,21-tetrol-20-one (Allo-TH-Cortisol) \\
\hline $\mathrm{a}-\mathrm{Cl}$ & 5ß-Pregnane-3a,17a,20aa,21-tetrol-11-one (a-Cortolone) \\
\hline$\beta-\mathrm{Cl}$ & $5 \beta$-Pregnane-3a,17a,20ß,21-tetrol-11-one ( $\beta$-Cortolone) \\
\hline $\mathrm{a}-\mathrm{C}$ & $5 \beta$-Pregnane-3a,11ß,17a,20a,21-pentol (a -Cortol) \\
\hline$\beta-C$ & $5 \beta$-Pregnane-3a11 $\beta, 17 a, 20 \beta, 21$-pentol ( $\beta$-Cortol) \\
\hline $6 \beta-\mathrm{OH}-\mathrm{F}$ & 4-Pregnene-6ß,11ß,17a,21-tetrol-3,20-dion \\
\hline 20a-DHF & 4-Pregnene-11 $\beta, 17 a, 20 a, 21$-tetrol-3-one \\
\hline 11-OH-An & 5a-Androstane-3a,11 $\beta$-diol-17-one \\
\hline $11-0-A n$ & 5a-androstane-3a-ol-11,17-dion \\
\hline 11-OH-Et & $5 \beta b$-androstane-3a,11ß-diol-17-one \\
\hline 11-0-PT & $5 \beta$-Pregnane-3a,17a,20a-triol-11-one \\
\hline THA & $5 \beta$-Pregnane-3a,21-diol-11,20-dion \\
\hline THB & $5 \beta$-Pregnane-3a,11ß,21-triol-20-one (TH-Corticosterone) \\
\hline a-THB & 5a-Pregnane-3a,11ß,21-triol-20-one (Allo-TH-Corticosteron) \\
\hline THS & $5 \beta$-Pregnane-3a,17a,21-triol-20-one \\
\hline E1 & Estrone \\
\hline E2 & Estradiol \\
\hline
\end{tabular}




\section{Declarations}

Ethics approval and consent to participate :REB approval for the study was received from Rambam Helsinki Committee (RMB) and all patients signed the informed consent for.

\section{Consent for publication-Not applicable}

Availability of data and materials-The datasets used and/or analysed during the current study are available from the corresponding author on reasonable request.

\section{Competing interests-The authors declare that they have no competing interests}

Funding- The funding for this research were from the local lab research funding, no external funding was received for this study.

Authors' contributions: YBA wrote the first draft of the manuscript and design the study, AK conduct the study, help to design the study and analyze the data, MFH- analyzed and interpreted the patient data conduct the laboratory study and was a major contributor in writing the manuscript SAW- analyzed and interpreted the patient data and was a major contributor in writing the manuscript DT- design the study and was a major contributor in writing the manuscript. All authors read and approved the final manuscript.

Acknowledgements- Ronit Leiba for conducting the statistical analysis

\section{References}

1. Arend, W. P. Physiology of cytokine pathways in rheumatoid arthritis. Arthritis Rheum, 45, 101-6 (2001).

2. Ivashkiv, L. B. Cytokine expression and cell activation in inflammatory arthritis. Adv. Immunol, 63, 337-76 (1996).

3. Spîrchez, M. et al. Relation of interleukin-6, TNF-alpha and interleukin-1alpha with disease activity and severity in juvenile idiopathic arthritis patients. Clin Lab, 58, 253-60 (2012).

4. Straub, R. H. \& Cutolo, M. Circadian rhythms in rheumatoid arthritis: Implications for pathophysiology and therapeutic management. Arthritis Rheum, 56, 399-408 (2007).

5. Straub, R. H. et al. Inadequately low serum levels of steroid hormones in relation to interleukin-6 and tumor necrosis factor in untreated patients with early rheumatoid arthritis and reactive arthritis. Arthritis Rheum, 46, 65462 (2002).

6. Aeschlimann, F. A. et al. A20 haploinsufficiency (HA20): clinical phenotypes and disease course of patients with a newly recognised NF-kB-mediated autoinflammatory disease. Ann Rheum Dis, 77, 728-35 (2018).

7. Hall, J. et al. Abnormal hypothalamic-pituitary-adrenal axis function in rheumatoid arthritis. Effects of nonsteroidal antiinflammatory drugs and water immersion. Arthritis Rheum, 37, 1132-7 (1994).

8. Horneff, G. Update on biologicals for treatment of juvenile idiopathic arthritis. Expert Opin Biol Ther, 13, 361-76 (2013).

9. Petty, R. E. et al. International League of Associations for Rheumatology classification of juvenile idiopathic arthritis: second revision, Edmonton, 2001. J Rheumatol, 31, 390-2 (2004). 
10. Wudy, S. A. et al. The art of measuring steroids: Principles and practice of current hormonal steroid analysis. $J$ Steroid Biochem Mol Biol, 179, 88-103 (2018).

11. Thierry, S. et al. Prevalence and incidence of juvenile idiopathic arthritis: a systematic review. Joint Bone Spine, 81, 112-7 (2014).

12. Bilginer, Y. et al. Low cortisol levels in active juvenile idiopathic arthritis. Clin Rheumatol, 29, 309-14 (2010).

13. Blanco, R. et al. Henoch-Schonlein purpura in adulthood and childhood: two different expressions of the same syndrome. Arthritis Rheum, 40, 859-64 (1997).

14. Picco, P. et al. Involvement of the hypothalamic-pituitary-adrenal axis in children with oligoarticular-onset idiopathic arthritis. Ann N Y Acad Sci, 966, 369-72 (2002).

15. Atzeni, F. et al. Anti-TNF therapy restores the hypothalamic-pituitary-adrenal axis. Ann N Y Acad Sci, 1193, 179-81 (2010).

16. Weidler, C. et al. Tumor necrosis factor inhibits conversion of dehydroepiandrosterone sulfate (DHEAS) to DHEA in rheumatoid arthritis synovial cells: A prerequisite for local androgen deficiency. Arthritis Rheum, 52, 1721-9 (2005).

17. Edwards, C. Sixty years after Hench-corticosteroids and chronic inflammatory disease. J Clin Endocrinol Metab, 97, 1443-51 (2012).

\section{Tables}

Table 1 Clinical characteristic of the patients with juvenile idiopathic arthritis

\begin{tabular}{|cllllllll|}
\hline & Sex & Age & JIA subtype & $\begin{array}{l}\text { Disease } \\
\text { duration } \\
\text { (years) }\end{array}$ & $\begin{array}{l}\text { No. of } \\
\text { active } \\
\text { joints }\end{array}$ & $\begin{array}{l}\text { CRP } \\
\text { levels } \\
\text { (mg/dl)* }\end{array}$ & $\begin{array}{l}\text { Treatment duration } \\
\text { with } \\
\text { etanercept (years) }\end{array}$ & $\begin{array}{l}\text { Etanercept dosage } \\
\text { (mg*1/w) }\end{array}$ \\
\hline 1 & F & 16 & $\begin{array}{l}\text { Psoriatic } \\
\text { arthritis }\end{array}$ & 3 & 0 & 3.6 & 0.7 & 50 \\
\hline 3 & M & 16 & Oligoarthritis & 4 & 0 & 0.5 & 3 & 50 \\
\hline 4 & F & 21 & Oligoarthritis & 18 & 3 & n/a & 10 & 50 \\
\hline 5 & M & 8 & Polyarthritis & 3 & 1 & 5.5 & 3 & 25 \\
\hline 6 & F & 15 & Polyarthritis & 7 & 0 & 8.6 & 6 & 50 \\
\hline 7 & F & 18 & Oligoarthritis & 15 & 0 & n/a & 5 & 50 \\
\hline 8 & M & 5 & Systemic & 4 & 0 & 0 & 3 & 25 \\
\hline 9 & F & 15 & Polyarthritis & 4 & 0 & 10.1 & 3 & 50 \\
\hline 10 & F & 15 & Psoriatic & 6 & 1 & 0 & 1 & 50 \\
\hline 11 & F & 3 & Polyarthritis & 2 & 0 & 0 & 0.6 & 7.5 \\
\hline
\end{tabular}

n/a, not available

Table 2 Urine metabolite values in the juvenile idiopathic arthritis patients and controls 


\begin{tabular}{|c|c|c|c|c|c|c|c|}
\hline \multirow[t]{2}{*}{ Metabolite } & \multicolumn{2}{|l|}{ Before etanercept } & \multicolumn{2}{|c|}{$\begin{array}{l}\text { One day after } \\
\text { etanercept }\end{array}$} & \multicolumn{2}{|c|}{$\begin{array}{l}\text { Three days after } \\
\text { etanercept }\end{array}$} & \multirow{2}{*}{$\begin{array}{l}\text { Control } \\
\text { group } \\
\text { Median, } \\
\text { (Min- } \\
\text { Max) } \\
\mu g / L\end{array}$} \\
\hline & $\begin{array}{l}\text { Median, (Min-Max) } \\
\mu \mathrm{g} / \mathrm{L}\end{array}$ & $\begin{array}{l}\mathrm{p} \\
\text { values } \\
\text { before } \\
\text { vs } \\
\text { controls }\end{array}$ & $\begin{array}{l}\text { Median, } \\
\text { (Min- } \\
\text { Max) } \\
\mu g / L\end{array}$ & $\begin{array}{l}\text { p values } \\
1 \text { day } \\
\text { after vs } \\
\text { controls }\end{array}$ & $\begin{array}{l}\text { Median, } \\
\text { (Min-Max) } \\
\mu g / L\end{array}$ & $\begin{array}{l}\mathrm{p} \\
\text { values } \\
3 \text { days } \\
\text { after vs } \\
\text { controls }\end{array}$ & \\
\hline \multicolumn{8}{|c|}{ C19-steroids (androgens) } \\
\hline An & $\begin{array}{l}427.81 \\
(17.97-2054.22)\end{array}$ & 0.003 & $\begin{array}{l}575.66 \\
(13.45- \\
1644)\end{array}$ & 0.019 & $\begin{array}{l}412.92 \\
(16.73- \\
4449.08)\end{array}$ & 0.008 & $\begin{array}{l}1192.54 \\
(81.57- \\
4116.32)\end{array}$ \\
\hline Et & $\begin{array}{l}392.54 \\
(24.68-3063.66)\end{array}$ & 0.09 & $\begin{array}{l}513.98 \\
(11.30 \\
4616.94)\end{array}$ & 0.4 & $\begin{array}{l}489.91 \\
(14.445773 .05)\end{array}$ & 0.4 & $\begin{array}{l}1145.88 \\
(87.36- \\
3525.82)\end{array}$ \\
\hline DHEA & $\begin{array}{l}392.54 \\
(24.68-3063.66)\end{array}$ & 0.8 & $\begin{array}{l}41.73 \\
(0- \\
2741.18)\end{array}$ & 0.8 & $\begin{array}{l}23.24 \\
(0-926.18)\end{array}$ & 0.4 & $\begin{array}{l}94.03 \\
(10.65- \\
2582.57)\end{array}$ \\
\hline $\begin{array}{l}\text { 16a-OH- } \\
\text { DHEA }\end{array}$ & $\begin{array}{l}25.79 . \\
(0-1536.30)\end{array}$ & 07 & $\begin{array}{l}92.51 \\
(0- \\
1621.95)\end{array}$ & 0.9 & $\begin{array}{l}125.21 \\
(0-1634.31)\end{array}$ & 0.8 & $\begin{array}{l}272.12 \\
(.00- \\
872.27)\end{array}$ \\
\hline A5-3b,17a & $\begin{array}{l}14.12 \\
(0-85.72)\end{array}$ & 0.0049 & $\begin{array}{l}14.94 \\
(0-159.06)\end{array}$ & 0.07 & $\begin{array}{l}19.03 \\
(.00-175.92)\end{array}$ & 0.2 & $\begin{array}{l}45.22 \\
(11.03- \\
112.41)\end{array}$ \\
\hline$A 5-3 b, 17 b$ & $\begin{array}{l}19.52 \\
(0-77.32)\end{array}$ & 0.3 & $\begin{array}{l}19.34 \\
(0-85.83)\end{array}$ & 0.31 & $\begin{array}{l}27.58 \\
(.00-106.72)\end{array}$ & 0.3 & $\begin{array}{l}41.18 \\
(.00- \\
358.93)\end{array}$ \\
\hline A5T-16a & $\begin{array}{l}87.25 \\
(0-1200.50)\end{array}$ & 0.9 & $\begin{array}{l}81.11 \\
(0- \\
1548.20)\end{array}$ & 0.9 & $\begin{array}{l}113.05 \\
(.00-2719.29)\end{array}$ & 0.6 & $\begin{array}{l}147.46 \\
(39.50- \\
566.38)\end{array}$ \\
\hline 11-OH-An & $\begin{array}{l}276.47 \\
(34.45-637.49)\end{array}$ & 0.0053 & 193.16 & 0.039 & 241.12 & 0.047 & 579.13 \\
\hline
\end{tabular}




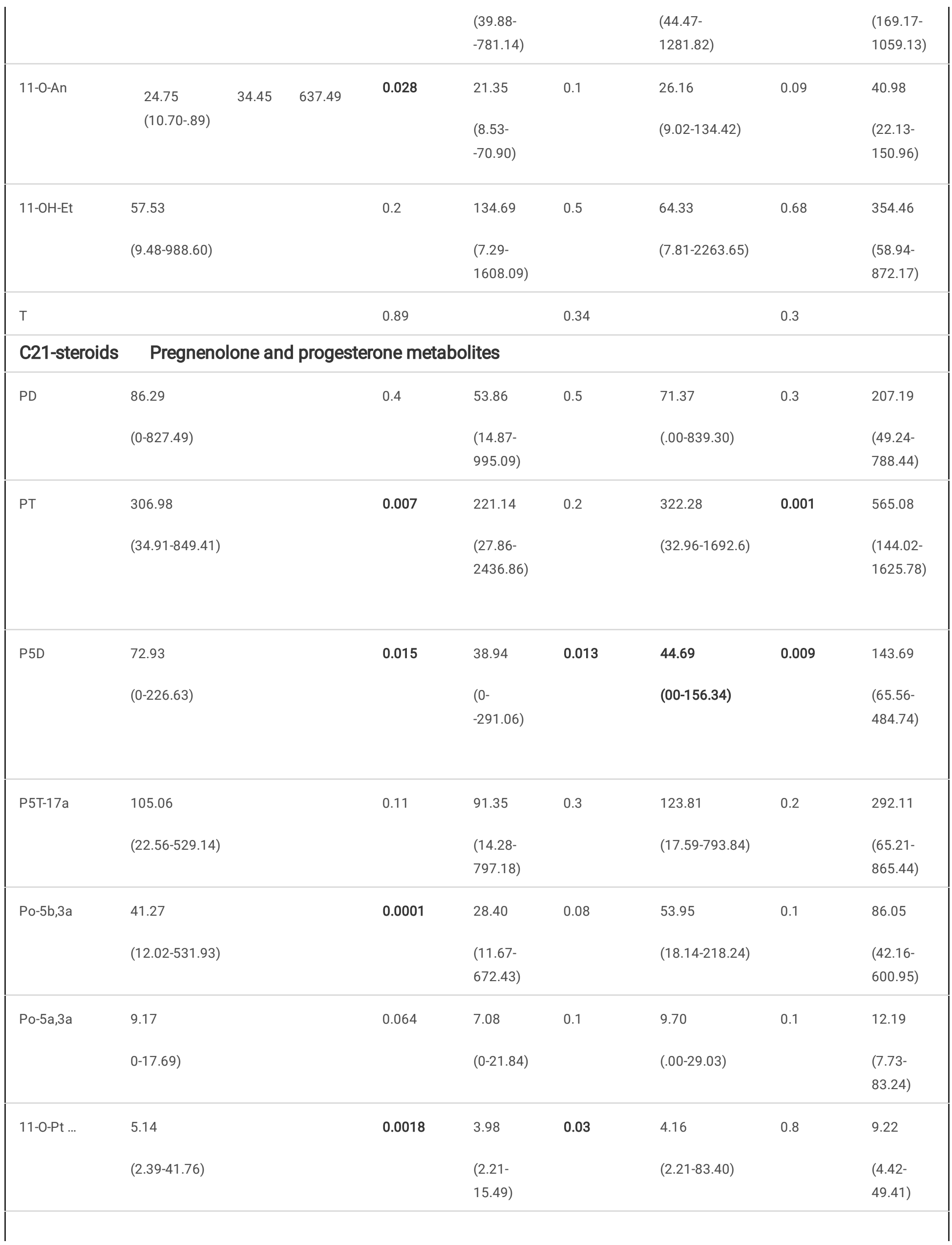




\begin{tabular}{|c|c|c|c|c|c|c|c|}
\hline THS & $\begin{array}{l}55.47 \\
(24.89-211.36)\end{array}$ & 0.0065 & $\begin{array}{l}57.22 \\
(24.71- \\
336.07)\end{array}$ & 0.1 & $\begin{array}{l}70.18 \\
(27.00-266.76)\end{array}$ & 0.16 & $\begin{array}{l}104.33 \\
(37.82- \\
295.79)\end{array}$ \\
\hline \multicolumn{8}{|c|}{ Cortisol metabolites } \\
\hline $\mathrm{F}$ & $40.21(20.62-134.45)$ & 0.025 & $\begin{array}{l}35.64 \\
(19.75- \\
266.41)\end{array}$ & 0.7 & $\begin{array}{l}44.20 \\
(24.59-219.24)\end{array}$ & 0.5 & $\begin{array}{l}74.27 \\
(28.16- \\
143.60)\end{array}$ \\
\hline THE & $\begin{array}{l}2467.00 \\
(534.81-5709.12)\end{array}$ & 0.022 & $\begin{array}{l}1881.51 \\
(541.44- \\
11880.03)\end{array}$ & 0.6 & $\begin{array}{l}1960.83 \\
(668.60- \\
11234.45)\end{array}$ & 0.2 & $\begin{array}{l}3396.78 \\
(831.73- \\
7896.67)\end{array}$ \\
\hline THF & $\begin{array}{l}871.67 \\
(205.93-1959.04)\end{array}$ & 0.028 & $\begin{array}{l}620.38 \\
(305- \\
3295.74)\end{array}$ & 0.4 & $\begin{array}{l}838.12 \\
(366-667.05)\end{array}$ & 0.3 & $\begin{array}{l}1097.69 \\
(420.88- \\
2403.82)\end{array}$ \\
\hline a-THF & $\begin{array}{l}434.13 \\
(47.59-1194.49)\end{array}$ & 0.016 & $\begin{array}{l}552.75 \\
(61.32- \\
1942.16)\end{array}$ & 0.3 & $\begin{array}{l}493.77 \\
(46.30- \\
2137.91)\end{array}$ & 0.1 & $\begin{array}{l}902.28 \\
(93.23- \\
1488.69)\end{array}$ \\
\hline $\mathrm{a}-\mathrm{Cl}$ & $\begin{array}{l}715.04 \\
254.56-1823.31)\end{array}$ & 0.012 & $\begin{array}{l}643.37 \\
(274.96- \\
4126.42)\end{array}$ & 0.6 & $\begin{array}{l}666.16 \\
(351.31- \\
2702.04)\end{array}$ & 0.03 & $\begin{array}{l}1246.88 \\
(598- \\
2701)\end{array}$ \\
\hline $\mathrm{b}-\mathrm{Cl}$ & $\begin{array}{l}388.41 \\
(68.26-1128.53)\end{array}$ & 0.001 & $\begin{array}{l}447.54 \\
(190 \\
-1435)\end{array}$ & 0.2 & $\begin{array}{l}461.83 \\
(58.38-1641.23\end{array}$ & 0.08 & $\begin{array}{l}705.23 \\
(126.71- \\
1402.16)\end{array}$ \\
\hline$a-C$ & $\begin{array}{l}86.79 \\
(38.58-241.82)\end{array}$ & 0.002 & $\begin{array}{l}85.60 \\
(37.80 \\
-458.59)\end{array}$ & 0.07 & $\begin{array}{l}99.09 \\
(46.28-489.07)\end{array}$ & 0.08 & $\begin{array}{l}182.45 \\
(52.43- \\
390.19)\end{array}$ \\
\hline$b-c$ & $\begin{array}{l}252.81 \\
(55.43-648.28)\end{array}$ & 0.014 & $\begin{array}{l}298.91 \\
(70.29- \\
801.36)\end{array}$ & 0.045 & $\begin{array}{l}248.15 \\
(45.41-894.96)\end{array}$ & 0.07 & $\begin{array}{l}513.62 \\
(105.74- \\
1615.79)\end{array}$ \\
\hline $6 \mathrm{~b}-\mathrm{OH}-\mathrm{F}$ & $\begin{array}{l}87.86 \\
(49.05-312.35)\end{array}$ & 0.02 & $\begin{array}{l}94.19 \\
(00-64.50)\end{array}$ & 0.1 & $\begin{array}{l}115.32 \\
(51.3-82)\end{array}$ & 0.5 & $\begin{array}{l}277.13 \\
(69.52- \\
503.68)\end{array}$ \\
\hline 20a-DHF & $\begin{array}{l}25.93 \\
(0-55.62)\end{array}$ & 0.03 & 23.54 & 0.1 & $\begin{array}{l}22.79 \\
(.00-103.23)\end{array}$ & 0.3 & 40.27 \\
\hline
\end{tabular}




\section{Corticosterone metabolites}

\begin{tabular}{|c|c|c|c|c|c|c|c|}
\hline \multirow[t]{3}{*}{ THA } & 101.69 & 0.034 & 83.84 & 0.49 & 117.02 & 0.07 & 274.83 \\
\hline & \multirow[t]{2}{*}{$(31.18-273.00)$} & & \multirow{2}{*}{\multicolumn{2}{|c|}{$\begin{array}{l}(25.20- \\
810 .)\end{array}$}} & \multirow{2}{*}{\multicolumn{2}{|c|}{$(45.77-396.07)$}} & (46.04- \\
\hline & & & & & & & 758.96) \\
\hline \multirow[t]{3}{*}{ THB } & 111.86 & 0.025 & 65.14 & 0.3 & 90.52 & 0.052 & 251.85 \\
\hline & \multirow[t]{2}{*}{$(32.22-445.00)$} & & $(.00-$ & & $(52.72-393.93)$ & & (81.56- \\
\hline & & & \multicolumn{2}{|l|}{ 631.76) } & & & 555.59) \\
\hline \multirow[t]{4}{*}{ a-THB } & \multirow[t]{2}{*}{170.58} & \multirow[t]{4}{*}{0.053} & 149.01 & 0.3 & 151.04(41.97- & 0.09 & 301.34 \\
\hline & & & & & 749.04) & & \\
\hline & \multirow[t]{2}{*}{$(26.20-360.73)$} & & \multirow{2}{*}{\multicolumn{2}{|c|}{$\begin{array}{l}(23.98- \\
-1426.28)\end{array}$}} & & & (39.35- \\
\hline & & & & & & & 1411.08) \\
\hline \multicolumn{8}{|c|}{ C18-steroids (estrogens) } \\
\hline \multirow[t]{2}{*}{ E1 } & \multirow[t]{2}{*}{$0(0-28.04)$} & \multirow[t]{2}{*}{0.040} & $0(0-$ & 0.3 & $0.00(0.00-$ & 0.19 & 18.33 (0- \\
\hline & & & 38.73) & & 24.52) & & 33.65) \\
\hline \multirow[t]{2}{*}{ E2 } & \multirow[t]{2}{*}{$0(0-7.87)$} & \multirow[t]{2}{*}{0.03} & \multirow[t]{2}{*}{$0(0-8.97)$} & \multirow[t]{2}{*}{0.1} & \multirow[t]{2}{*}{$6.00(0-7.24)$} & \multirow[t]{2}{*}{0.3} & $5.77(0-$ \\
\hline & & & & & & & 13.41) \\
\hline \multirow[t]{3}{*}{ E 3} & \multirow[t]{3}{*}{$0(0-30.13)$} & \multirow[t]{3}{*}{0.29} & \multirow{3}{*}{$\begin{array}{l}0(0- \\
42.68)\end{array}$} & \multirow[t]{3}{*}{0.2} & \multirow[t]{3}{*}{$5.77(0-13.41)$} & \multirow[t]{3}{*}{0.4} & 0.00 \\
\hline & & & & & & & $(0.00-$ \\
\hline & & & & & & & $95.86)$ \\
\hline
\end{tabular}

Significant values $(p<0.05)$ appear in bold

Min, minimum; Max, maximum

Table 3 Urine metabolites ratios that reflect enzyme activities 


\begin{tabular}{|c|c|c|}
\hline Enzyme & Ratio & $p$ value \\
\hline 21-hydroxylase & THE+THF+aTHF)/PT & 0.06 \\
\hline \multirow[t]{2}{*}{ 17-hydroxilase } & $(\mathrm{THE}+\mathrm{THF}+\mathrm{aTHF}) /(\mathrm{THA}+\mathrm{TH} \mathrm{B}+\mathrm{aTHB})$ & 0.39 \\
\hline & $(\mathrm{An}+\mathrm{Et}) /(\mathrm{THA}+\mathrm{THB}+\mathrm{aTHB})$ & 0.57 \\
\hline 11b-hydroxylase & $(\mathrm{THE}+\mathrm{THF}+\mathrm{aTHF}) / 100 * T H S:$ & 0.32 \\
\hline \multirow[t]{2}{*}{ 11b-hSD2 } & THE/ (THE +a THF ) & 0.53 \\
\hline & $(a-C l)+(b-C l)) /(a-C+b-C)$ & 0.38 \\
\hline \multirow{2}{*}{$\begin{array}{l}\text { 11b-HSD1 } \\
\text { (liver, adip) }\end{array}$} & (THF+aTHF)/THE: & 0.95 \\
\hline & $(a-C l+b-C l) /(a-C l+b-C l):$ & 0.07 \\
\hline \multirow[t]{4}{*}{5 a-reductase } & $\mathrm{An} / \mathrm{Et}$ & 0.28 \\
\hline & 11-OH-An/11-OH-Et & 0.65 \\
\hline & $\mathrm{aTHB} / \mathrm{THB}$ & 0.78 \\
\hline & aTHF/THF & 0.89 \\
\hline
\end{tabular}

Significant values $(p<0.05)$ appear in bold

\section{Figures}




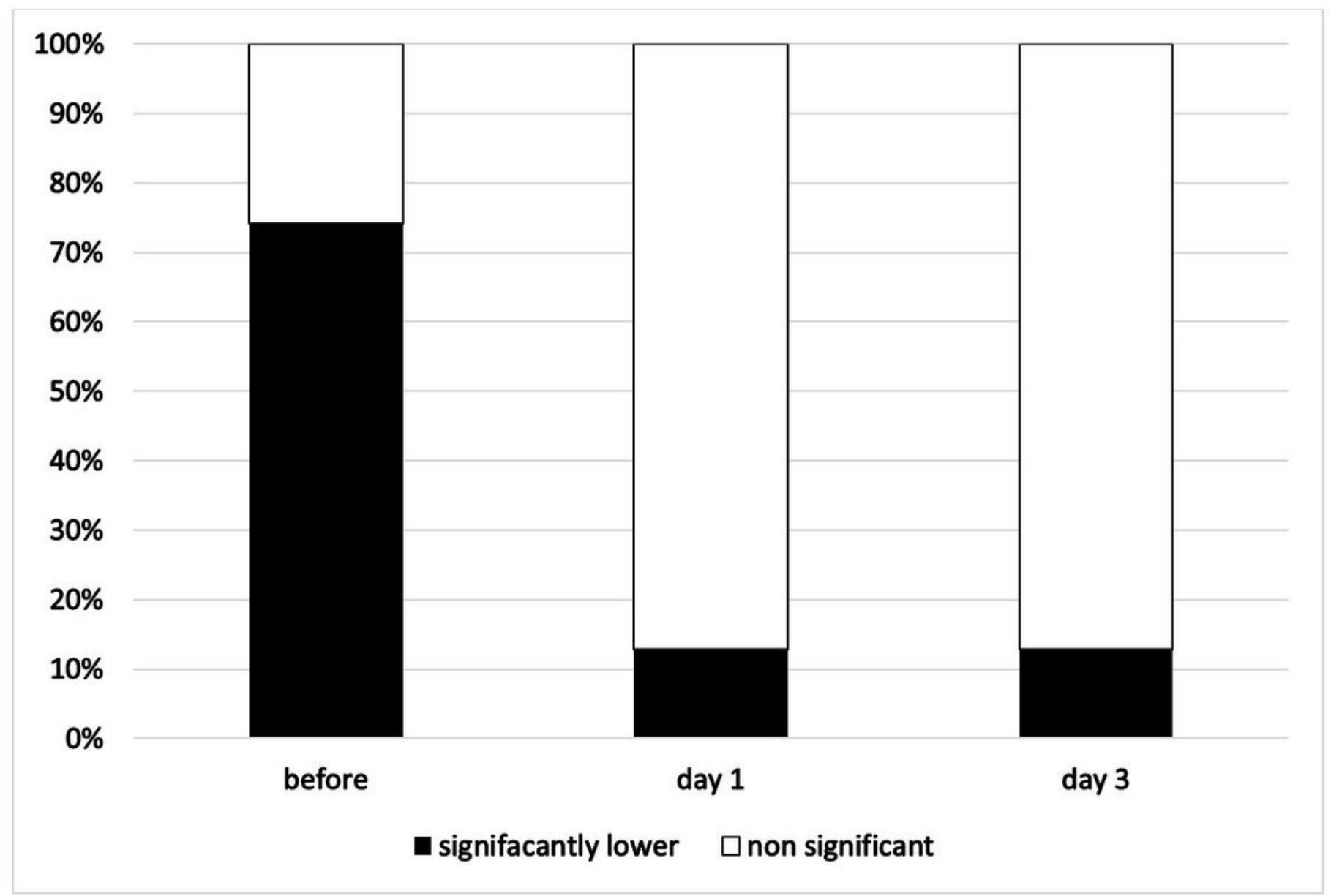

Figure 1

The black columns represent the percentage of significantly lower levels of adrenal metabolites in urine and the white columns represent the percentage of normal metabolites before and after etanercept treatment. 